\title{
Polishing of AIN/sapphire substrates obtained by thermochemical nitridation of sapphire
}

\author{
E.A.Vovk, A.T.Budnikov, S.V.Nizhankovskyi, S.I.Kryvonogov, \\ A.A.Krukhmalev, M.V. Dobrotvorskaya \\ Institute for Single Crystals, STC "Institute for Single Crystals", National \\ Academy of Sciences of Ukraine, 60 Lenin Ave., 61001 Kharkiv, Ukraine
}

Received December 27, 2012

\begin{abstract}
Physicochemical conditions and polishing suspension composition were established for polishing of AIN/sapphire templates obtained by thermochemical nitridation of sapphire. The use of the polishing suspension based on aerosil and $\mathrm{KOH}$ with $\mathrm{pH} 10.3$ allowed to prepare the surface with a roughness $R_{a}$ up to $1 \mathrm{~nm}$. The morphology and element composition of AIN/sapphire surface at layer-by-layer removal of the nitridated layer were studied by the methods of atomic force microscopy and X-ray photoelectronic spectroscopy.
\end{abstract}

\begin{abstract}
Разработаны физико-химические условия и состав суспензии для полирования композитных подложек AIN/сапфир, полученных методом термохимической нитридизации сапфира. Использование полировальной суспензии на основе аэросила с $\mathrm{KOH}$ при $\mathrm{pH}$ 10.3 позволило получить поверхность с шероховатостью $R_{a}$ до 1 нм. Методами атомносиловой микроскопии и рентгеновской фотоэлектронной спектроскопии изучена морфология и элементный состав поверхности AIN/сапфир при послойном полировании нитридизованного слоя.
\end{abstract}

\section{Introduction}

Semiconductor heterostructures based on III-Nitride materials are widely used in opto- and microwave electronics. Due to close values of thermal expansion coefficients and relatively small discrepancy in the crystal lattice parameters, aluminum nitride (AIN) is the most suitable materials to be used as a substrate for epitaxy of heterostructures of aluminum, gallium nitrides and their solid solutions. However, at present there are no effective technologies for the growth of AIN crystals. The maximum diameter of AIN substrates does not exceed 2 inches, and their cost is extremely high. An alternative approach is the use of composite aluminum nitride substrates (templates), obtained by formation of crystalline aluminum nitride layer put onto a relatively inexpensive base, such as sapphire. Templates are also obtained by the methods of gas phase epitaxy. Earlier we have shown the possibility to produce crystalline aluminum nitride layers on sapphire (AIN/sapphire) by thermochemical nitridation (TCN) of sapphire [1]. The essence of this method is the following. While annealing sapphire at temperatures of $1300-1450^{\circ} \mathrm{C}$ in nitrogen-containing atmosphere under reductive conditions, there occurs nitridation of the surface layer followed by the formation of the crystalline phase of aluminum nitride with a varying composition $\operatorname{AIN}(\mathrm{O})$ and the structure of wurtzite. The thickness of the formed layer reaches 1 and $2 \mu \mathrm{m}$ for sapphire substrates with the crystallographic orientations (0001) and (10I2), respectively. The surface morphology depends on the morphology and crystalline orientation of the initial sapphire substrate, the conditions of nitridation, and $R_{a}$ may exceed 5-10 nm.

The goal of the present work was to establish the conditions for polishing of the 

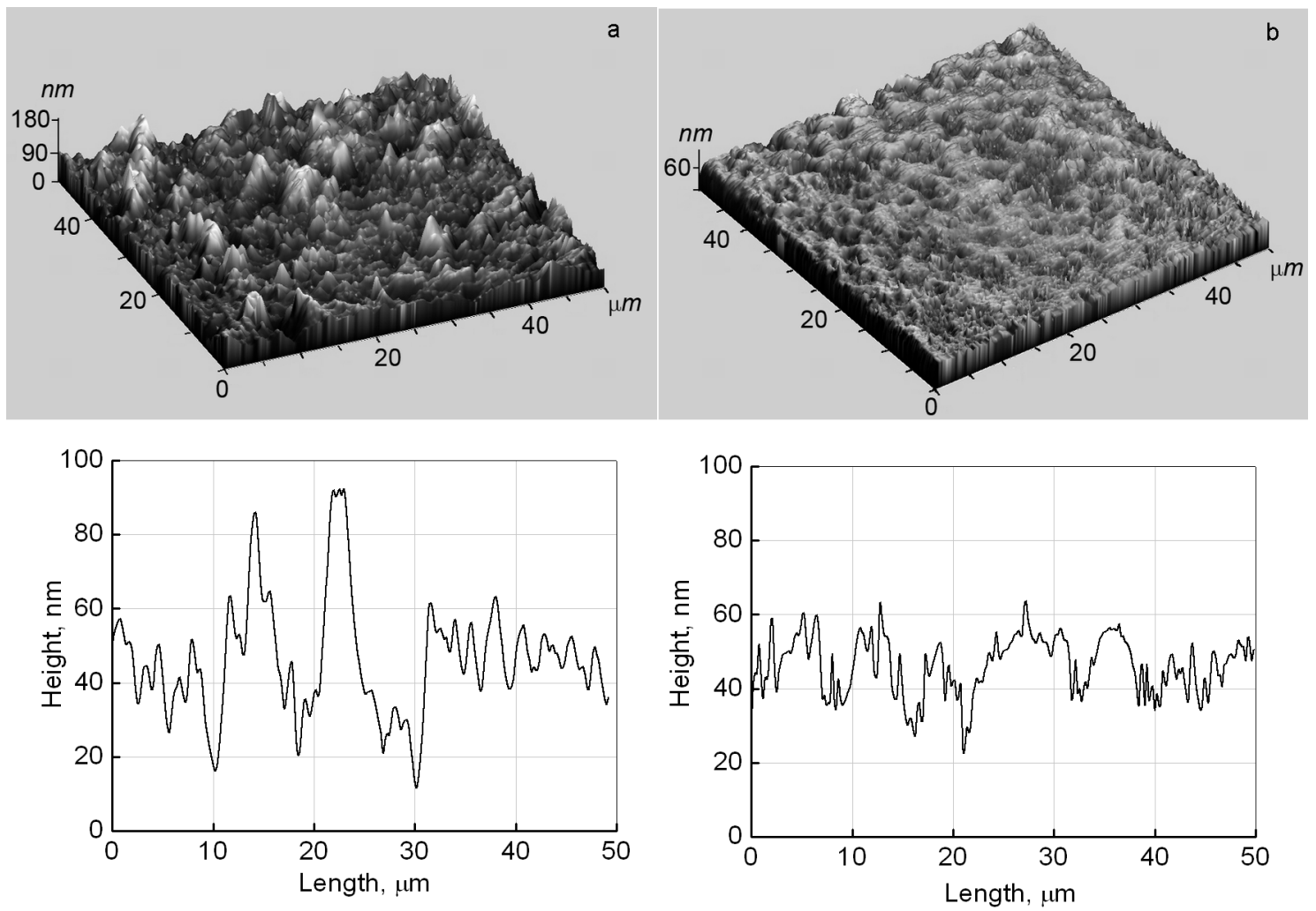

Fig. 1. 3D-image and profilogram of the surface of AIN/sapphire template on sapphire substrate after MP (a) and CMP (b).

structures AIN/sapphire templates obtained by the TCN method, and to study the morphology and element composition of the surface at layer-by-layer removal of the nitridated surface.

\section{Experimental}

The study was performed on AIN(0001)// $\mathrm{Al}_{2} \mathrm{O}_{3}(0001)$ samples. The initial sapphire substrates had a diameter of $50.8 \mathrm{~mm}$, their surface was treated by mechanical or chemical-mechanical polishing (MP and CMP, respectively) The polished substrates were nitridated during $5 \mathrm{~h}$ in a furnace with graphite thermal unit containing a mixture of nitrogen with the gaseous reductants $\mathrm{CO}$ and $\mathrm{H}_{2}(<1$ vol. $\%)$ under a pressure of $0.1 \mathrm{MPa}$ at $1400-1450^{\circ} \mathrm{C}$. The thickness of AIN layers was determined by means of X-ray diffractometry from the intensity of the interference lines in the sym- metrical Bragg geometry and run into 0.1$0.3 \mu \mathrm{m}$. The element composition of the nitridated layer was determined by the method of X-ray photoelectron spectroscopy (XPS) using a spectrometer of XPS-800 Kratos. The composition of the sample surface was established from the ratio of the areas of the lines of $\mathrm{O} 1 s, \mathrm{Al} 2 p, \mathrm{~N} 1 s$ - core levels taking into account the sensitivity coefficients. The thickness of the analyzed layer was of about $5 \mathrm{~nm}$. The morphology and roughness of the nitridated sapphire surface was examined by means of atomicforce microscopy (AFM) on a scanning probe microscope Solver P47H PRO (NT-MDT) and on an interference microscope MII-4, the flatness was determined using an interferometer of IT-200 type.

MP of the nitridated sapphire samples were carried out diamond paste ACM 28/20. For CMP there were used polishing suspen-

Table 1. Composition of polishing suspensions based on silicon dioxide

\begin{tabular}{||c|c|c|c|c||}
\hline & Suspension & Size of $\mathrm{SiO}_{2}$ particles, $\mathrm{nm}$ & Addition & $\mathrm{pH}$ \\
\hline 1 & Aerosil + water & 10-20 nm for primary particles, & surfactant & 4.5 \\
\cline { 5 - 5 } 2 & Aerosil + water & up to $1 \mu \mathrm{m}$ for agglomerates & $\mathrm{KOH}$ & 10.3 \\
\hline 3 & Nalco & 60 & $\mathrm{KOH}$ & 10.8 \\
\hline
\end{tabular}



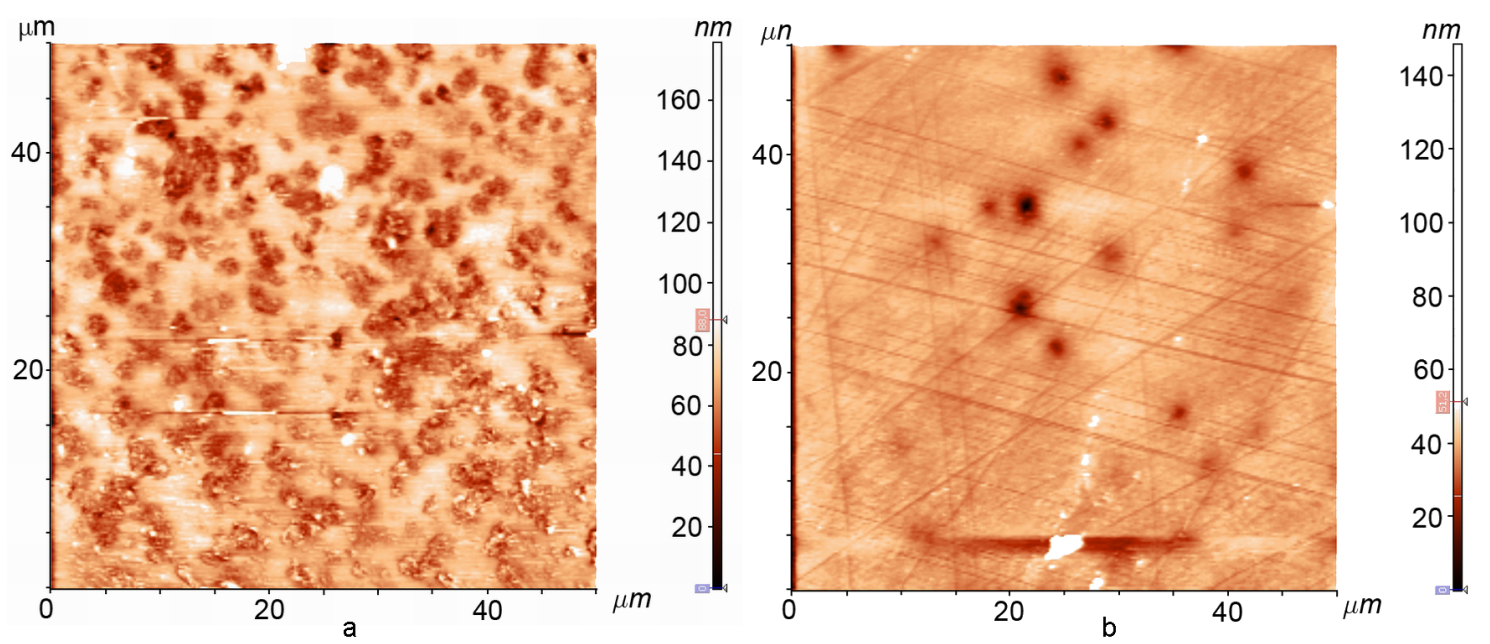

Fig. 2. Surface of AIN/sapphire template at polishing with suspension 1: within 10 min (a), within $60 \min (b)$.

sions based on silicon dioxide with the compositions shown in Table 1. Suspension 1 usually applied to CMP of sapphire, contained aerosil (pyrogenic $\mathrm{SiO}_{2}$ with the size of primary particles $10-20 \mathrm{~nm}$ ), water and surfactants which reduced agglomeration of highly-dispersed aerosil particles. Suspension 2 was prepared from aerosil, water and $\mathrm{KOH}$, the suspension $\mathrm{pH}$ was 10.3. It is known, $\mathrm{KOH}$ interacts with nitrides of trivalent elements such as GaN or AIN, and can be used for etching the surface of the corresponding single crystals [2,3], as well as for chemico-mechanical polishing $[4,5]$. According to [6], in this case the chemical reaction proceeds according to the equation $\mathrm{AIN}+6 \mathrm{KOH}=\mathrm{Al}(\mathrm{OH})_{3}+\mathrm{NH}_{3}+3 \mathrm{~K}_{2} \mathrm{O}$. Suspension 3 was the one produced by Nalco with the addition of $\mathrm{KOH}$.

\section{Results and discussion}

The data of AFM microscopy proved that the morphology of the initial sapphire substrate is one of the factors which define the morphology of the nitridated surface. After being subjected to MP and CMP the roughness of the sapphire substrates $R_{a}$ was 14.4 and $0.3 \mathrm{~nm}$, respectively. Due to nitridation these values increased up to 18 and $7.7 \mathrm{~nm}$, respectively (Fig. 1). The AIN surface with an initial roughness of $7.7 \mathrm{~nm}$ contained hills with a diameter up to $0.1 \mu \mathrm{m}$ and a height up to $20 \mathrm{~nm}$, the depth of individual pores was $20 \mathrm{~nm}$.

The samples were polished by suspension 1 . In the process of polishing the hills flattened and their area gradually increased (Fig. 2). Thereat, the surface contained individual pores with a depth up to $10 \mathrm{~nm}$.
Table 2. Atomic concentrations of elements in the surface layer of polished AIN/sapphire template (XPS data)

\begin{tabular}{|c|c|c|c|c|c||}
\hline \multirow{2}{*}{$\begin{array}{c}\text { Polishing } \\
\text { time, min }\end{array}$} & \multicolumn{5}{|c||}{ Atomic concentration, \% } \\
\cline { 2 - 6 } & Al & O & N & C & Si \\
\hline 0 & 35.9 & 12.0 & 20.0 & 32.1 & - \\
25 & 34.8 & 25.4 & 5.0 & 33.4 & 1.4 \\
60 & 35.3 & 27.6 & 1.2 & 33.9 & 2.0 \\
\hline
\end{tabular}

Within $60 \mathrm{~min}$ of polishing the surface roughness was $2.49 \mathrm{~nm}$.

In [7] the hills formed on the surface are attributed to accumulation of the energy of compressive strain, due to an essential $(13.2 \%)$ difference in the crystal lattice parameters between the nitridated layer and sapphire. After reaching a critical point the energy of compressive strain gives rise to displacement caused by stress. The formation of the hills reduces the excessive energy.

According to X-ray data, within $10 \mathrm{~min}$ of polishing the phase AIN is not revealed on the surface. However, XPS testifies that nitrogen atoms are present on the surface within $60 \mathrm{~min}$ of polishing. The element composition of the surface at layer-by-layer removal of the nitridated surface is presented in Table 2.

The observed gradual decrease of the concentration of nitrogen atoms at step-bystep removal of the nitridated surface by polishing confirmed the fact that the mechanism of sapphire nitridation is diffusive. In [7] $7 \mathrm{~nm}$ thick nitridated layer formed as a result of sapphire nitridation with ammonia in the process of MOVPE at $1200^{\circ} \mathrm{C}$ is described as an amorphous layer 


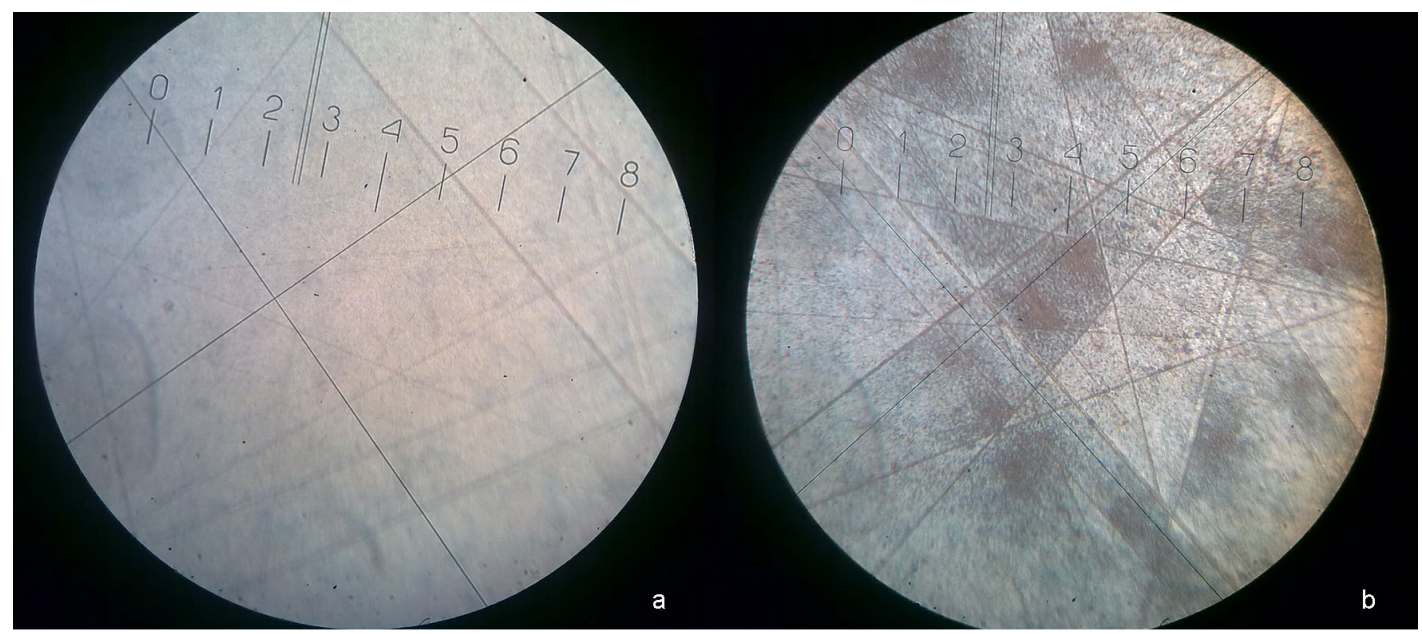

Fig. 3. Morphology of AIN surface on sapphire substrate after MP: initial (a), within 40 min of polishing with suspension 2 (b). Scale unit $30 \mu \mathrm{m}$.
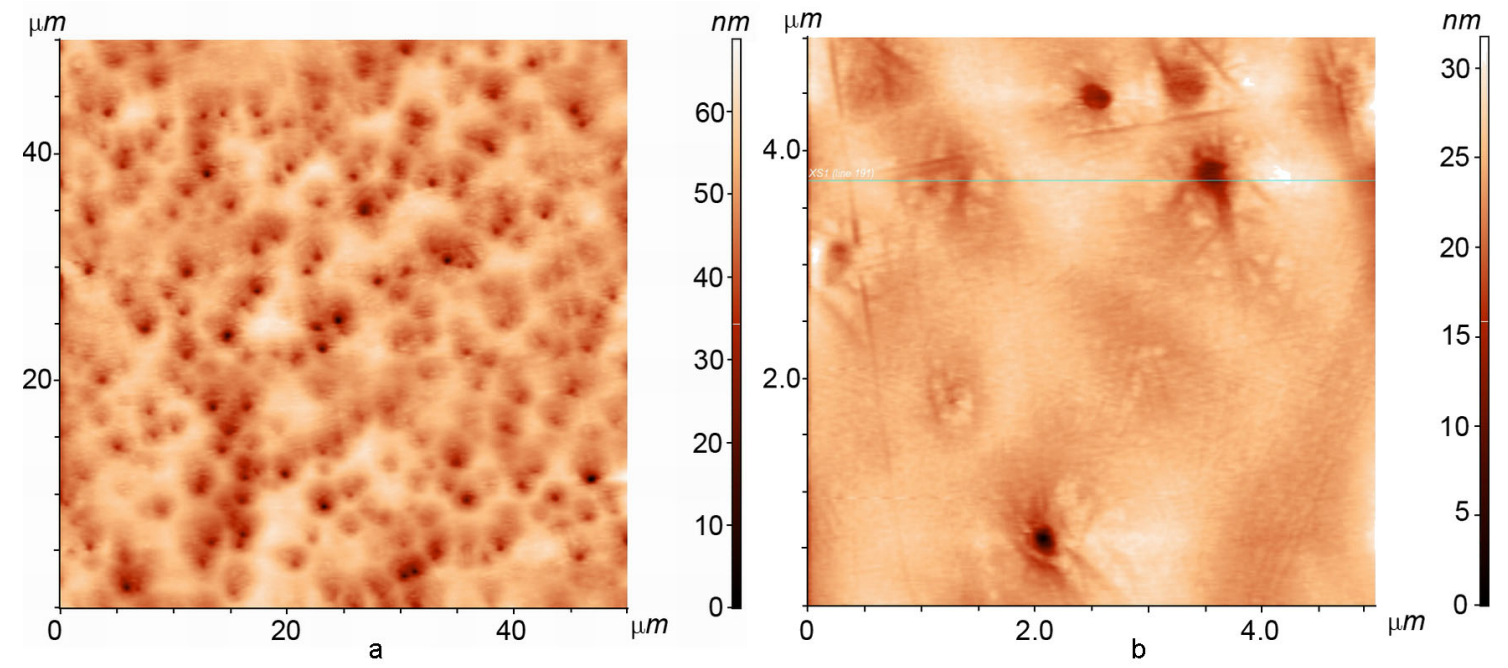

Fig. 4. Surface of AIN/sapphire template in the process of polishing with suspension 2: within 10 min (a), within 60 min (b).

containing fragments of partially crystalline structure $\mathrm{AIN}_{x} \mathrm{O}_{1-x}$ with varying composition. Since $\mathrm{TCN}$ is conducted at higher temperatures $\left(1450^{\circ} \mathrm{C}\right)$ thus favoring the processes of diffusion, the thickness of the nitridated layer in our samples (up to $1 \mu \mathrm{m}$ for $\left.\mathrm{AIN}(0001) / / \mathrm{Al}_{2} \mathrm{O}_{3}(0001)\right)$ essentially exceeds the corresponding value observed at nitridation by the methods of MOVPE [8] or MOCVD [9]. When using TCN the formation of AIN layer has two stages [10]. At first, sapphire is diffusively saturated with nitrogen under reducing conditions, that is followed by the formation of $\mathrm{Al}_{2} \mathrm{O}_{3}: \mathrm{N}$ solid solution with varying composition and the structure of corundum in a diffusion region (limited by the mobility of anionic vacancies). Then decomposition of the supersaturated solution and crystallochemical trans- formations followed by the formation of AIN phase occur in the surface layer with a density considerably lesser than the one of the diffusion region, after reaching some critical concentration of nitrogen.

After polishing of AIN/sapphire template by means of suspension 1 , the quality of the obtained surface was unsatisfactory. The surface contained a large quantity of scratches with a width up to $0.1 \mu \mathrm{m}$ (Fig. 2, b). The use of this suspension obviously gave rise to abrasive treatment of the surface caused by $\mathrm{SiO}_{2}$ particles that did not allow to obtain the surface without defects. The net of scratches formed on the surface treated with suspension 1 is characteristic of mechanical polishing. To raise the surface quality, the polishing suspension was supplemented with $\mathrm{KOH}$ that re- 

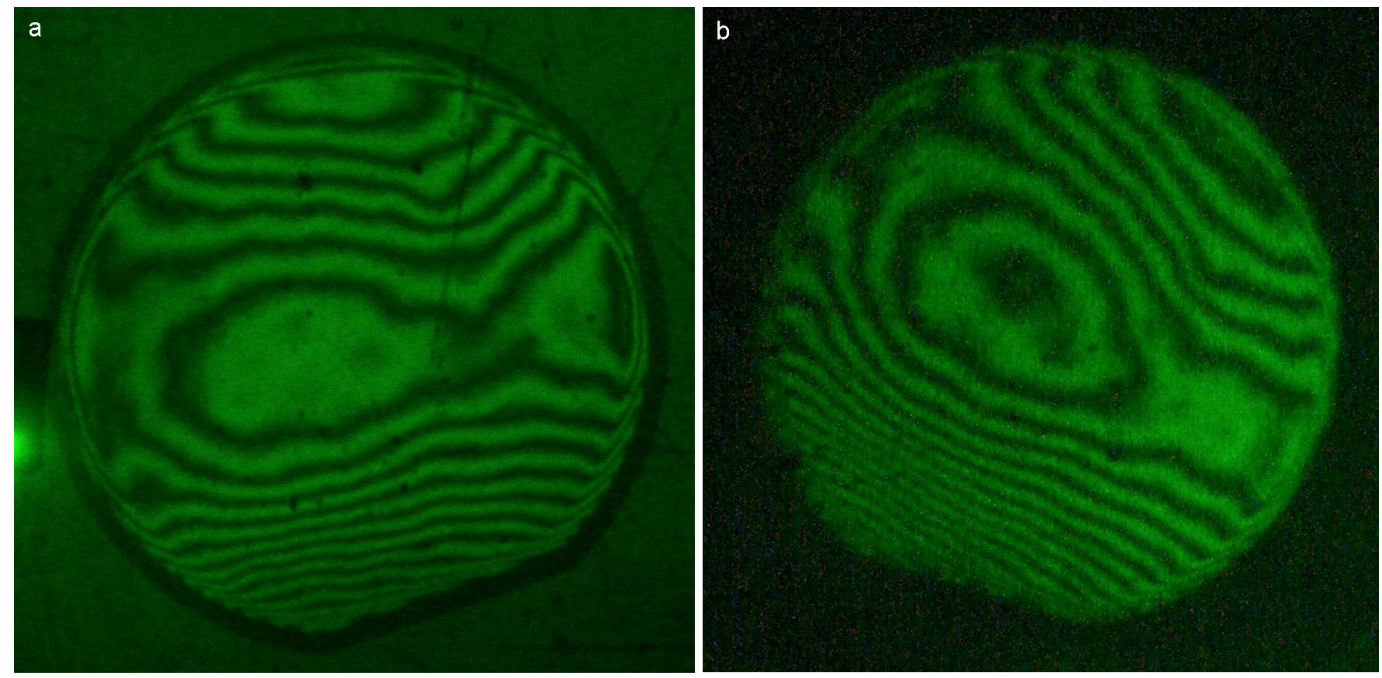

Fig. 5. Interference patterns of AIN/sapphire template before (a) and after polishing (b).
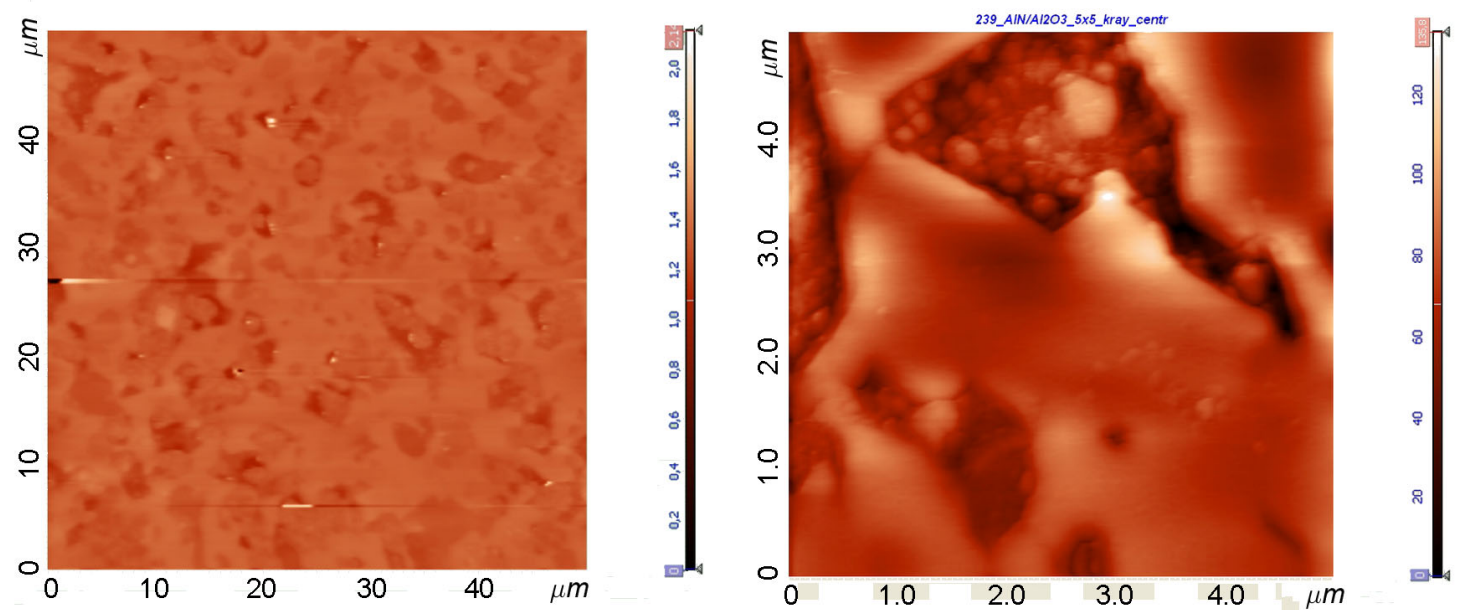

Fig. 6. Surface of AIN/sapphire template in the process of polishing with suspension 3: scan $50 \times 50 \mu \mathrm{m}^{2}$ (a), scan $5 \times 5 \mu \mathrm{m}^{2}(\mathrm{~b})$.

sulted in the rise of the suspension $\mathrm{pH}$ 10.3. Suspension 2 was used to polish AIN layers obtained on sapphire substrate which surface was preliminarily subjected to MP and CMP. The nitridated layer was morphologically inhomogeneous on the substrate after MP. On the surface of AIN there were observed individual regions with the structure of the surface of the initial sapphire substrate, in particular, scratches (Fig. 3, a). After polishing the regions of the layer limited by scratches had different appearance and different residual density (Fig. 3, b) obviously due to the fact that they had different initial film thickness or different structure.

The surface of AIN layer obtained on the sapphire substrate after CMP, did not contain such inhomogeneities, as sapphire substrates treated by CMP had no surface de- fects (scratches) characteristic of mechanically polished surface. The surface polished using suspension 2 had practically no scratches in the bulk of the nitrogen-containing layer (Fig. 4). Within $60 \mathrm{~min}$ of polishing the surface roughness was $0.95 \mathrm{~nm}$. However, even in the case when the content of nitrogen on the surface (determined by XPS) diminished to $1 \%$, the individual funnel-shaped pores with a depth up to $10 \mathrm{~nm}$ were remained on the surface (Fig. 4, b). This may be caused by dissociative decomposition of sapphire followed by the appearance of gaseous products which form pores while reaching the surface.

The thickness of the nitridated layer was estimated form the loss of the mass of the polished samples in the process of CMP. The thickness of the layer removed at polishing of the nitrogen-containing layer was found 
to be almost twice as large in comparison with that of AIN layer determined by X-ray method.

Due to an essential (36.4\%) distinction in the values of thermal expansion coefficient of $\mathrm{AIN}$ and $\mathrm{Al}_{2} \mathrm{O}_{3}$ one could expect change of the substrate flatness at nitridation. However, after the removal of the nitridated layer the interference pattern for AIN/sapphire template remains practically unchanged (Fig. 5). This seems to be caused either by the fact that the nitridated layer thickness is too small to distort the substrate flatness or by the varying composition of the nitridated layer.

The samples were also polished using suspension 3 produced by Nalco (silicon dioxide in the form of $\mathrm{NaOH}$-stabilized sol) with $\mathrm{KOH}$ introduced in the capacity of active chemical agent, the suspension $\mathrm{pH}$ was 10.8. In the process of polishing there was observed etching of the surface defects. The protruding parts of the hills flattened, the depth and size of the pores increased (Fig. 6, a). The surface roughness changed from 7.7 to $39.2 \mathrm{~nm}$. The pore edges became faceted, some pores had the shape of hexahedron. Inside the pores there were contained agglomerates of faceted crystallites (Fig. 6, b). The observed process resembles etching of the surface of sapphire with the crystallographic orientation (0001) at CMP using the given suspension produced by Nalco.

\section{Conclusions}

It is established that the suspension based on silicon dioxide in the form of aerosil with $\mathrm{KOH}$ at $\mathrm{pH} 10.3$ is most suitable for chemical-mechanical polishing AIN $(0001) / / \mathrm{Al}_{2} \mathrm{O}_{3}(0001)$ templates, as it allows to obtain a smooth surface practically without scratches and a roughness up to $1 \mathrm{~nm}$. The nitridated layer formed on sapphire substrate after mechanical polishing is found to be inhomogeneous as far as the morphology is concerned. It seems probable that the residual substrate surface defects may give rise to the formation of nitridated layer areas with different thickness and structure. The study of the surface morphology in the process of layer-by-layer polishing of the nitridated layer $\operatorname{AIN}(0001)$ points to the presence of pores in it.

\section{References}

1. H.S.-ogly Kaltaev, N.S.Sidelnikova, S.V.Nizhankovskiy et al., Fizika i Tehnika Poluprovodnikov, 43, 1650 (2009).

2. J.H.Edgar et al., J.Cryst. Growth, 246, 187 (2002).

3. M.Bickermanna, S.Schmidta, B.M.Epelbauma et al., J.Cryst. Growth, 300, 299 (2007).

4. Y.Huaiyue, X.Xiangqian, L.Zhanhui et al., $J$. Semiconduct., 30, 023003 (2009).

5. U.S. Patent 7,037,838 (2006).

6. D.Zhuanga, J.H.Edgara, B.Strojekb et al., J. Cryst. Growth, 89, 262 (2004).

7. K.Uchida, A.Watanabe, F.Yano et al., J.Appl. Phys., 79, 3487 (1996).

8. Jong-Sik Paek, Kyoung-Kook Kim, Ji-Myon Lee et al., J.Cryst. Growth, 200, 55 (1999).

9. A.Rice, R.Collazo, J.Tweedie et al., J.Appl. Phys., 108, 043510 (2010).

10. S.V.Nizhankovskiy, A.A.Kruhmaljov, N.S.Sidelnikova et al., Fiz.Tverd.Tela, 54, 1777 (2012).

\title{
Полірування структур AIN/caпфip, виготовлених термохімічною нітридизацією сапфіру
}

\author{
О.О.Вовк, О.Т.Будніков, С.В.Ніжанковський, С.І.Кривоногов, \\ А.О.Крухмальов, М.В.Добротворська
}

\begin{abstract}
Розроблено фізико-хімічні умови та склад суспензії для полірування композитних підкладок AIN/сапфір, виготовлених методом термохімічної нітридизації сапфіру. Використання полірувальної суспензії на основі аеросилу з КОН при рН 10.3 дозволило отримати поверхню 3 шорсткістю $R_{a}$ до 1 нм. Методами атомно-силової мікроскопії та рентгенівської фотоелектронної спектроскопії досліджено морфологію та елементний склад поверхні AIN/сапфір при пошаровому поліруванні нітридизованого шару.
\end{abstract}

